\title{
Drivers of Audit Quality for the Development of the Audit Quality Framework based on the International Standards
}

\author{
Nurna Aziza, Andi Agus
}

\begin{abstract}
Audit quality has a role so important that various parties, including investors, creditors, regulators, and management, depend on financial information generated by the auditor to make decisions. Although it plays a very important role in auditing, the measurement of audit quality has not yet been agreed upon. By adopting various standards and perspectives developed by various world-leading institutions, this study revisits the importance of the role of building a theoretical model of audit quality in the midst of its complexity. In this context, this study seeks to develop a theoretical review of the factors driving audit quality and develop a model framework for the development of auditing and audit quality research in future accounting scientific research.
\end{abstract}

Keywords: audit quality, driving factors, framework, international standards.

\section{INTRODUCTION}

Audit quality has a role so important that various parties, including investors, creditors, regulators, and management, depend on financial information generated by the auditor to make decisions. Arruñada (2000) emphasizes the important role of auditors in audit quality in ensuring the reliability of accounting information. Peecher, et al (2007) suggested that the reliability of accounting information began to be questioned since the rise of accounting scandals. The rise of accounting scandals at the beginning of the 21 st century is a bad phenomenon about the low audit quality produced by independent auditors. This phenomenon can be interpreted as evidence: (a) The failure of auditors in detecting fraud committed by companies (Barton, 2005). (b) The high number of auditors involved in accounting scandals committed by companies (Peecher, et al, 2007). (c) Range of auditors against intimidation (pressure) from clients (Knapp, (1985). (d) Denial by a number of auditors for the high trust given by the public (Skinner and Srinivasan, 2010). (e) High litigation costs to be borne by auditors (Free, 1999; Pratt and Stice, 1994).

The failure of the auditor to detect fraud, the auditor's involvement in accounting scandals, and the auditor's vulnerability to client pressure raises various problems and questions. Problems that arise are the rise of capital market penalties, litigation, lawsuits, and the collapse of the auditor's reputation (Skinner and Srinivasan, 2010; Barton, 2005) and

Revised Manuscript Received on November 22, 2019

Nurna Aziza, Universitas Bengkulu, Bengkulu, Indonesia.

Andi Agus, Sekolah Tinggi Ilmu Ekonomi Makassar Bongaya, Makassar, Indonesia. the high practice protection costs that must be paid by the auditor.

Although it plays a very important role in auditing, the measurement of audit quality has not yet been agreed upon. Therefore, some researchers take a different approach to measuring audit quality. By adopting various standards and perspectives developed by various world-leading institutions, this study revisits the importance of the role of building a theoretical model of audit quality in the midst of its complexity. In this context, this study seeks to develop a theoretical review of the factors driving audit quality and develop a model framework for the development of auditing and audit quality research in future accounting scientific research.

\section{RESULT AND DISCUSSION}

\section{A. Audit Quality: Between complexity and its role}

The Financial Reporting Council (2006) and Bonner (2008) state that audit quality is a complex concept and cannot be defined simply. This is in line with Power (1997) which shows uncertainty about the concept of audit quality that is clearly in accordance with facts on the ground and existing standards. This is caused by: (a) the difficulty of audit quality is observed and measured directly, especially by creditors and investors (Skinner and Srinivasan, 2012). (b) The role and expectations of audit market participants on audit quality differ (Sutton, 1993). (c) Audit quality measures will tend to be defined differently for many parties (Warming-Rasmussen \& Jensen, 1998; Watkins, Hillison, and Morecraft, 2004). Therefore, audit quality is a different matter for different people (Wooten, 2003).

As a consequence of the absence of agreement on the definition of audit quality is expected to make it used as a standard to assess performance, the definition of audit quality depends on what angle each party sees it (Tangpinyoputtikhun and Thammavinyu, 2010). That is, the use of different dimensions makes the definition of audit quality different so that audit quality proxies are also different (Francis, 2004).

As a result of the absence of key definitions resulting in theoretical and practical differences and problems in measuring audit quality, namely how to determine the high and low audit quality, and how to determine a reliable method for measuring audit quality accurately. Therefore, some researchers take a different approach to measuring audit quality.

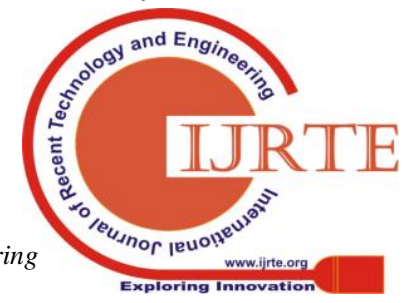




\section{B. Audit Quality Framework from PCAOB}

The Public Company Accounting Oversight Board (PCAOB) (2013) defines audit quality as meeting the needs of investors for independent and trustworthy audit services as well as good communication between the audit committee and external auditors regarding financial statements including disclosure of financial statements, guarantees of internal control and going concern (see, Fakhimuddin, 2018). Based on the definition of audit quality, PCAOB (2013) developed a framework for audit quality covering three segments, namely audit input, audit process and audit results as illustrated in Figure 1.

The audit input segment is related to various dimensions of human factors, including elements: staff workload, audit team, professional experience, continuing education, supervision and review, and partner workload. Each element is related to auditor competence and is very important for audit quality. The audit process segment includes elements: audit quality control standards, internal controls, audit risk assessments based on professional skepticism, objectivity, and independence. While the audit results segment includes; reliable financial reports including disclosures, internal control guarantees, going concern warnings, and audit committee communications. This segment as intuitive and conceptual is aligned with the auditor's work to produce audit quality. Thus, the audit quality measurement indicators offered by PCAOB (2013) are more comprehensive because they include the inputs, processes and results of conducting audits.

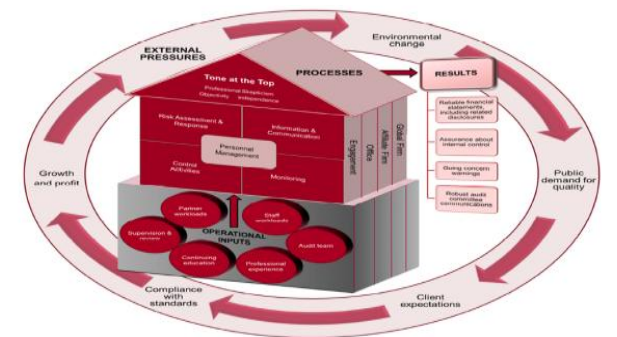

Figure 1. PCAOB Quality Framework Audit

Source: PCAOB (2013)

The audit quality framework developed by PCAOB (2013) also explains that the quality of audit activities and results occurs at several levels, namely at the level of global companies, affiliated companies, local companies, and audit teams. In addition, the audit quality framework also shows that there are external pressures that affect audit quality, such as a rapidly changing environment, public demand for quality, stakeholder expectations, compliance with standards, and pressure to develop and benefit.

\section{Audit Quality Framework of IAASB}

IAASB (2014) developed an audit quality framework that illustrates factors that contribute to audit quality. The audit quality framework developed by IAASB (2014) consists of: input, output, interaction, and context. Audit input includes: (a) Auditor values, ethics, and attitudes that can be emphasized by organizational culture (b) Professional knowledge, which is connected with the amount of carrying out work and time in audit work. (c) The effectiveness of audit quality control processes and procedures. The audit output includes: reliable and timely financial reports. The nature of the output can be affected by requirements, laws, and stakeholders.

Interactions include: interactions with key stakeholders, regulations (laws), investors, and others. Interaction with key stakeholders has a certain impact on audit quality. This interaction includes communication both formal and informal which will affect the context in which the audit is conducted. This interaction also allows for a dynamic relationship between input and output. For example, contents and form of audit reports are influenced by the experience and intensity of the relationship between the auditor in carrying out his duties with related parties in relation to the management of audit procedures and processes from planning to presentation of the report.

Many factors contribute to improving audit quality, and there are scores that can describe the factors that encourage stakeholders to improve audit quality. Each stakeholder is separate in each audit process has a role that influences the process and output of financial statements, and the extent to which the audit role can be carried out.

Context elements include: corporate governance, the applicable financial reporting framework, and regulations. Contextual factors can facilitate the quality of financial reporting, influence audit risk, the nature / level of audit evidence required, and the efficiency of the audit process. The audit quality framework developed by IAASB (2014) is shown in Figure 2.

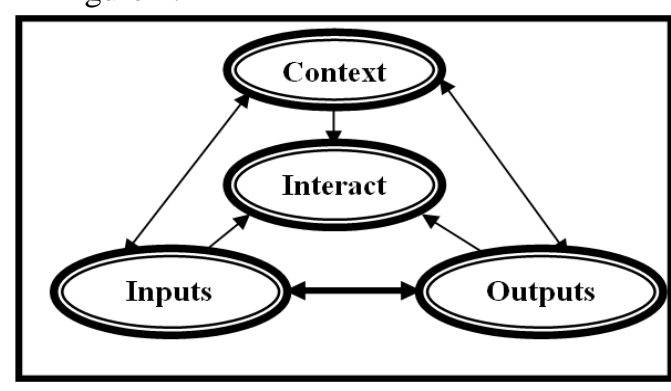

Figure 2. IAASB Quality Framework Audit Source: IAASB (2014)

\section{Input, Process, and Output}

Based on the description of the two frameworks, the audit quality chain contains of: audit input, audit process, and audit output. Audit inputs include: competence (knowledge and experience) and independence (the personal ethics section). The audit process includes the alignment of work (compliance) with auditing standards, and accounting standards. Audit output includes stakeholder perceptions of the accuracy of financial statements.

Audit quality viewed from the viewpoint of competence and independence (input) is explained by DeAngelo (1981a) as the possibility of finding and reporting a violation in the audit process and client relations.

This emphasizes three aspects, namely: (a) The probability of the auditor finding and reporting violations / fraud in the client's accounting system. (b) The auditor's knowledge and ability to find violations / fraud in the company's financial statements, whether intentional or unintentional. (c) The auditor's initiative to disclose violations or fraud. The auditor's ability to find violations is influenced by several things, such as the ethical orientation held by the auditor and his technical abilities (Deis and Giroux, 1992).

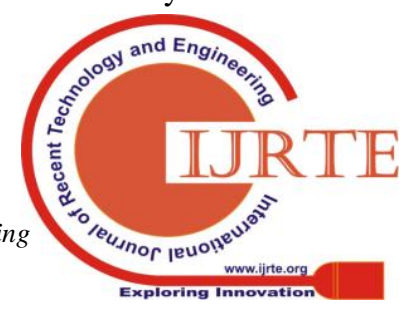


This argument is supported by Wooten (2003) who states that audit quality is related to the extent to which the auditor is able to find a violation and report it in accordance with the applicable system. This also refers to the ability of auditors to find fraud and report it depends on the auditor's ability and independence.

The argument can be interpreted that: (a) Probability is the auditor's ability to find violations / fraud that occur based on his knowledge and experience and his determination to report the violation / fraud. (b) The discovery of a violation is a measure of quality related to the auditor's knowledge and experience. (c) Reporting violations / fraud relating to independence. This indicates that the value of an audit lies in the auditor's knowledge and independence.

The American Accounting Association's Financial Accounting Committee (2000) states that audit quality is determined by two things, namely: competence and independence. Both of these have a direct effect on audit quality. That is, measures of audit quality related to auditor competence and independence. This is in line with Arens et al. (2012) who defines audit quality as how capable the statements and reporting them in accordance with the accounting system. Detection refers to capabilities, while reporting is related to the ethical side of the auditor, specifically the auditor's independence.

Audit quality is seen from the perspective of the process defined by the Government Accounting Office of the United States (2008) that audit quality is a measurement of the audit process carried out in accordance with applicable general standards so that the trust of clients and stakeholders regarding the presentation of financial statements can be obtained. in accordance with GAAP (generally accepted accounting principles) and free from material misstatement. Watkins, et al (2004) define audit quality as how well the audit is carried out according to auditing standards.

Boyton, et al (2006) define the quality of auditing as the degree of good or bad quality of a systematic inspection process. Good if the high quality degree is in accordance with GAAS (generally accepted auditing standards) and bad if the quality degree is not in accordance with GAAS. So a quality audit is a systematic inspection process in accordance with GAAS, so that it can find material errors in the audited financial statements. This is in line with Tan and Kao (1999) which states that audit quality is assessed by how much the auditor gives the correct response from each audit work completed. Correct responses are responses that are in accordance with GAAS.

Audit quality seen from the perspective of the report (audit results) is defined by Lee, Liu, and Wang (1999) that audit quality as a possible partner does not issue unqualified reports for financial statements that contain significant misstatements. Palmrose (1988) states that audit quality is related to the reliability of financial statements. Here, the accuracy of the information presented will be very important and influential, so that stakeholders will give the trust to the auditor because the financial statements are presented in accordance with generally accepted and reliable standards (Epstein and Geiger, 1994).

\section{E. Drivers of Audit Quality}

The definition and argument of audit quality mentioned above can be concluded that the notion of audit quality can be reviewed from three aspects namely; in terms of auditors, in auditor finds errors in presenting the client's financial

terms of the audit process, and in terms of audit reports. Thus, the definition of audit quality in this study combines these three things by defining audit quality as a combination of a good systematic inspection process (in accordance with GAAS) with good professional judgment from competent and independent auditors, to produce a level of assurance that is high quality to users of audit services (Knechel, 2007).

The public accounting profession is a profession related to stressful work (Weick, 1983). This argument is supported by Knapp (1985) who states that in connection with their work which provides an assessment of the relevant parties, the auditor is often faced with problems of disputes, and client pressure. This is intended so that the auditor gives an assessment in accordance with the client's request even though it is wrong according to applicable accounting standards. The client also tries to pressure the auditor to deviate from accounting principles (Goldman and Barlev, 1974). Thus, client pressure on the auditor at the time of the audit can negatively affect the auditor's work, namely audit quality.

\section{F. Audit Quality Framework for Future Research}

The theoretical model of this research uses the perspective of audit quality input based on human resources (auditor). Resource Based View (RBV) is often used to explain ownership of strategic resources for the creation of quality products in order to achieve sustainable competitive advantage (Wenerfelt, 1984). This argument is supported by Peteraf and Barney (2003) that the main function of the RBV is to explain that the resources owned provide benefits for the company, specifically a factor that can create sustainable competitive advantage.

Previous research documents the auditor's strategic testing resources that can influence audit quality such as professional knowledge (Tangpinyoputtikhun and Ussahawanitchakit, 2008; Lin and Hwang, 2010; Abdolmohammadi and Wright, 1987), and auditor ethics (Tangpinyoputtikhun and Thammavinyu, 2010; Gendron, et al., 2006).

Bender (2006) developed a theoretical framework that explains that the inputs that drive audit quality improvement are culture and human resources. Culture includes corporate governance, leadership, business performance, decision making involvement, ethics, and risk management. Human resources include basic skills, proper training, and performance evaluation. Culture encourages maximum partner participation, the quality of audit staff, rigorous processes and good judgment to produce audit reports that are informative and reliable, and job satisfaction of audit staff. Human resources encourage the creation of good communication.

The quality audit framework developed by DeFond et al. (2013) in line with Skinner and Srinivasan (2010) explains that there are two things that motivate auditors to improve audit quality, namely; reputation incentives and incentives to avoid litigation. Reputation incentives motivate auditors to improve audit quality in order to maintain stakeholder confidence in financial statements and obtain brand image from clients and stakeholders. Litigation incentives motivate auditors to improve audit quality in order to avoid capital market penalties or lawsuits from third parties. 


\section{Drivers of Audit Quality for the Development of the Audit Quality Framework based on the International Standards}

\section{CONCLUSION}

This study aims to revisit the importance of the role of building a theoretical model of audit quality in the midst of its complexity. Moreover, this study seeks to develop a theoretical review of the factors driving audit quality and develop a model framework for the development of auditing and audit quality research in future accounting scientific research. This is motivated by the considerations that audit proxies and measurements have weaknesses, including that auditors can be said to be qualified only measured by indicators of operational auditors to conduct audit assignments, or only measured by indicators of audit report results, or a combination of operational inputs and audit results, so that these studies do not yet reflect comprehensive audit quality.

This study revealed that the audit quality framework consists of audit input, audit process, and audit output. Audit inputs include competence (knowledge and experience) and independence (the personal ethics section). The audit process includes the alignment of work (compliance) with auditing standards, and accounting standards. Audit output includes stakeholder perceptions of the accuracy of financial statements. Moreover, from the driving factor, there are two things that motivate auditors to improve audit quality, namely; reputation incentives and incentives to avoid litigation. Reputation incentives motivate auditors to improve audit quality in order to maintain stakeholder confidence in financial statements and obtain brand image from clients and stakeholders. Litigation incentives motivate auditors to avoid capital market penalties or lawsuits from third parties through improving audit quality.

\section{REFERENCES}

1. Abdolmohammadi, M., \& Wright, A. (1987). An examination of the effects of experience and task complexity on audit judgments. Accounting Review, 1-13.

2. American Accounting Association's Financial Accounting Committee. (2000). Commentary: SEC Auditor Independece Requirements. Accounting Horizons 15(4), 373-386.

3. Ardelean, A. 2013. Auditors' ethics and their Impact on Public Trust. Procedia - Social and Behavioral Science 92, 55-60.

4. Arens, A. A., Elder, R. J., \& Mark, B. (2012). Auditing and assurance services: an integrated approach. Boston: Prentice Hall.

5. Arruñada, B. (2000). Audit quality: attributes, private safeguards and the role of regulation. European Accounting Review, 9(2), 205-224.

6. Barton, J. 2005. Who Cares about Auditor Reputation?. Contemporary Accounting Research 22(3), 549-586.

7. Bender R. (2006). What is an effective audit and how can you tell? Audit Committee Chair Forum, 1-13

8. Bonner, S. E. (2008). Judgment and decision making in accounting. Prentice Hall.

9. Boynton, W., Jhonson, R., Kell, W. (2006), Modern Auditing. 8th ed. USA: Richard D. Irwin Inc.

10. DeAngelo, L. E. (1981). Auditor size and audit quality. Journal of accounting and economics, 3(3), 183-199.

11. DeFond, M., Erkens, D. H., \& Zhang, J. (2016). Do client characteristics really drive the Big $\mathrm{N}$ audit quality effect? New evidence from propensity score matching. Management Science, 63(11), 3628-3649.

12. Deis Jr, D. R., \& Giroux, G. A. (1992). Determinants of audit quality in the public sector. Accounting Review, 462-479.

13. Epstein, M.J., \& Geiger, M.A. (1994). Investor views of audit assurance: recent evidence of the expectation gap. Journal of Accountancy 177, 60-66.

14. Fakhimuddin, M. (2018). Reconsidering Accounting Information Systems: Effective Formulations for Company's Internal Control. Arthatama Journal of Business Management and Accounting, 2(1)

15. Financial Reporting Council (2006). Financial reporting council the combined code on corporate governance. Retrieved from https://www.frc.org.uk/document-library/corporate-governance/2006/c ombined-code-(october-2006)

16. Francis, J. R. (2004). What do we know about audit quality?. The British accounting review, 36(4), 345-368.

17. Free, C., 1999. Limiting Auditor Liability. Bond Law Review, No. 11, 118-135.

18. Gendron, Y., \& Bédard, J. (2006). On the constitution of audit committee effectiveness. Accounting, Organizations and Society, 31(3), 211-239.

19. Goldman, A., \& Barlev, B. (1974). The auditor-firm conflict of interests Its implications for independence. The accounting review, 49(4), 707-718.

20. Government Accounting Office of the United States (2008). 2008 Financial Report of the United States Government Accounting Office. Washington DC: Government Accounting Office of the United States

21. International Auditing and Assurance Standards Board/IAASB. (2014). 2014 Handbook of International Quality Control, Auditing, Review, Other Assurance, and Related Services Pronouncements. The International Federation of Accountants (IFAC).

22. Knapp, M. C. (1985). Audit conflict: An empirical study of the perceived ability of auditors to resist management pressure. Accounting Review, 202-211.

23. Knechel, W. R. (2007). The business risk audit: Origins, obstacles and opportunities. Accounting, Organizations and Society, 32(4-5), 383-408.

24. Lee, C.J., Liu, C., \& Wang, T. (1999). The 150-hour Rule. Journal of Accounting and Economics 27(2), 203-228.

25. Lin, J. W., \& Hwang, M. I. (2010). Audit quality, corporate governance, and earnings management: A meta-analysis. International Journal of Auditing, 14(1), 57-77.

26. Palmrose, Z. V. (1988). 1987 Competitive Manuscript Co-Winner: An analysis of auditor litigation and audit service quality. Accounting review, 55-73.

27. Peecher, M. E., Schwartz, R., \& Solomon, I. (2007). It's all about audit quality: Perspectives on strategic-systems auditing. Accounting, Organizations and Society, 32(4-5), 463-485.

28. Peteraf, M. A., \& Barney, J. B. (2003). Unraveling the resource-based tangle. Managerial and decision economics, 24(4), 309-323.

29. Power, M. (1997). The audit society: Rituals of verification. OUP Oxford.

30. Pratt, J., and J. Stice. 1994. The Effects of Client Characteristics on Auditor Litigation Risk Judgment, Required Audit Evidence, and Recommended Audit Fees. Accounting Review 68, 639 - 656.

31. Skinner, D. J., \& Srinivasan, S. (2012). Audit quality and auditor reputation: Evidence from Japan. The Accounting Review, 87(5), 1737-1765.

32. Sutton, S. G. (1993). Toward an understanding of the factors affecting the quality of the audit process. Decision Sciences, 24(1), 88-105.

33. Tan, H. T., \& Kao, A. (1999). Accountability effects on auditors performance: The influence of knowledge, problem-solving ability, and task complexity. Journal of Accounting Research, 37(1), 209-223.

34. Tangpinyoputtikhun, Y., \& Ussahawanitchakit, P. (2008). Professional knowledge, audit quality, and personal image: an empirical study of tax auditors in Thailand. International Journal of Business Research, 8(1) 176-190.

35. Tangpinyoputtikhun. Y., and Thammavinyu. C 2010. The Impact of Professional Knowledge and Personal Ethics on Audit Quality and Sustainable Reputation of Thai-Public Accountants. Journal of Academy of Business and Economics, Volume 10 (2), 1-20.

36. The Public Company Accounting Oversight Board/PCAOB. (2013) Proposed auditing standards. Retrieved from https://pcaobus.org/Rulemaking/Docket034/Release_2013-005_ARM. pdf

37. Warming-Rasmussen, B., \& Jensen, L. (1998). Quality dimensions in external audit services-An external user perspective. European Accounting Review, 7(1), 65-82.

38. Watkins, A. L., Hillison, W., \& Morecroft, S. E. (2004). Audit quality: A synthesis of theory and empirical evidence. Journal of accounting literature, 23, 153.

39. Weick, K. E. (1983). Stress in accounting systems. The Accounting Review, 58(2), 350-369.

40. Wernerfelt, B. (1984). A resource-based view of the firm. Strategic management journal, 5(2), 171-180.

41. Wooten, T. C. (2003). Research about audit quality. The CPA Journal, 73(1), 48 